\title{
Developing Tutorials for several Institutional Partners: a real challenge! \\ Développer des tutoriels pour plusieurs institutions partenaires : un réel défi !
}

\section{Brigitte Belzile}

\begin{abstract}
This case describes the two-year development of a set of interactive tutorials for students and faculty at a number of community colleges and one university in order to target information literacy skills among their students, primarily searching for and evaluating information found online. The tools created were published under a Creative Commons license and made available to faculty members and instructors for the purposes of both online and classroom delivery. The main problems encountered dealt with collaboration issues arising between participating institutions, the availability and skill sets of the main contributors and the beta testing of materials developed for the target clientele.
\end{abstract}

Keywords: information literacy, instructional design, collaboration, technology-enhanced tools, tutorial, website, ADDIE

\section{Institutional context}

When Luke was hired at Northern University (NU) as an instructional designer, one of his first assignments was a collaborative project involving not only NU but also four large community colleges located in the same area (Figure 1). The project, dubbed Vivacity, was made possible by a development grant obtained a few weeks prior to Luke's arrival. 
For some time now, faculty and instructors had been requesting help developing information literacy skills among their students, specifically skills related to conducting online research, finding the right keywords, using Google and other databases, evaluating references, identifying instances of plagiarism, and so on. In short, the targeted information literacy skills were those that they and their students needed to be successful in their work or studies.

The main objective of this project was the design and development of instructional materials to support faculty and instructors in their course design, namely information literacy tutorials. The materials developed would be published on a website that was open to all institutional partners and eventually to the general public.

\section{The main players}

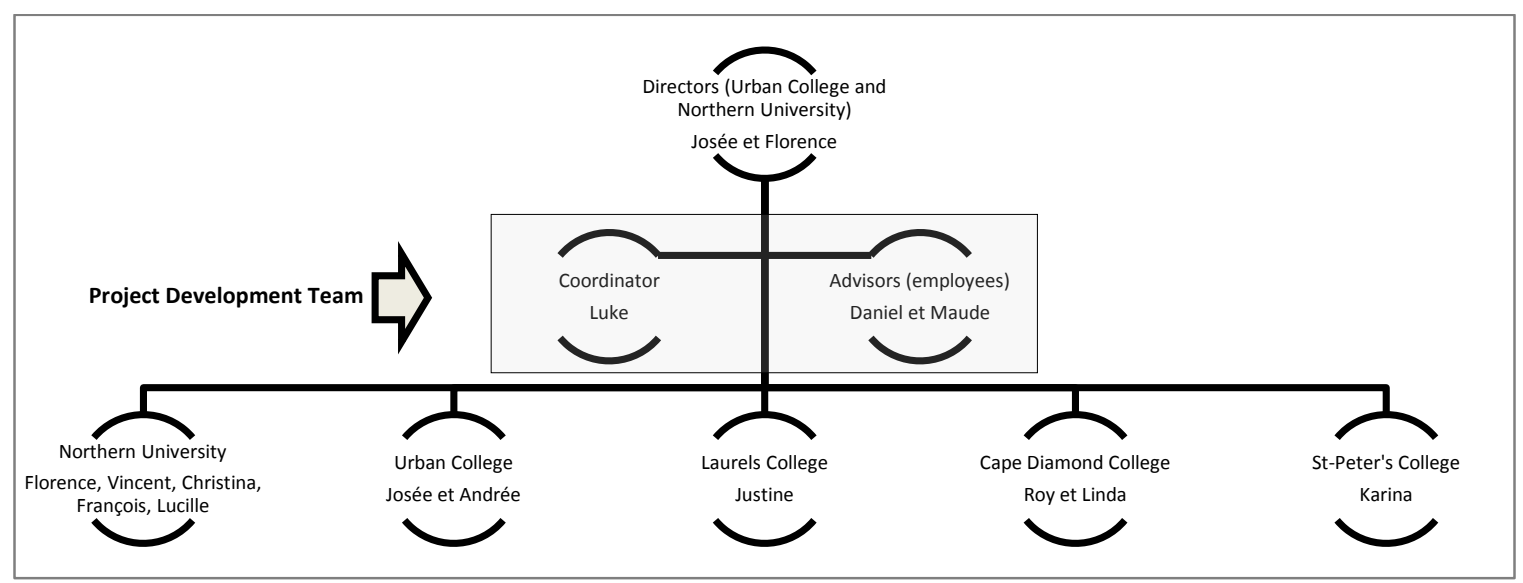

Figure 1 - Project administrative structure

- Two directors: Florence at NU and Josée at Urban College (UC)

- A Steering Committee appointed by the institutions: Cristina, Justine, Josée, Karina, Roy, Vincent 
- Luke, an experienced Instrumental Designer recently hired by NU

- Daniel, an experienced Community College instructor with expertise in information literacy, assigned full-time to the project and working mainly from home $(300 \mathrm{kms}$ from NU)

- Maude, a recent Information Sciences graduate with a specialty in Information Literacy and Information Technologies, assigned full-time to the project

\section{Development and implementation stages}

\section{Redefinition of the project}

A year had elapsed between the writing of the Vivacity project and obtaining the grant. One of Luke's first tasks in the initial stages of development of the project was to reframe several components. At the Steering Committee meeting, he presented a hard copy of an intricate conceptual map he had made of the project; on the big screen, it would have been unreadable.

Vincent (Steering Committee member): If you publish the tutorials just in Flash, some students won't be able to read them. So we should make sure the tutorials can be accessed using various mobile technologies.

Karina: But do students use these technologies? To the best of my knowledge, they use phones but not necessarily smart phones.

Justine: In my college classroom, computers are still banned by most instructors! We are still far from the iPad!

Luke: We could integrate a technology upgrade into the project in order to anticipate a possible conversion of Flash tutorials into other formats. I think we all know that Adobe and Apple are going to remain competitors for a long time to come! Anyway, if we can believe the last Educause Horizon Report, such an upgrade should be considered, if not right away, then soon.

Shortly after the meeting, the two subject matter experts (SMEs), Daniel and Maude, joined the

project. The project could finally get underway! 


\section{Establishing work processes}

At the first project meeting with the SMEs, Luke presented an overview of the project:

Daniel: Do you know if we can we use existing Web-based instructional resources?

Luke: Yes, if they meet our basic criteria. Students and faculty often complain that the current sites are boring, poorly organized, and difficult to navigate. To offer something more interesting, designed for real and practical learning, we need to propose short and dynamic resources, which are action-oriented rather than passive reading-based aids.

Daniel: I get the idea. I know a lot of websites on information literacy but they generally only offer text-based materials.

Luke: Well, information resources serve an important purpose and may be of some use to us. Indeed, there are a lot of good resources on the Web but, as we all know, most sites are in English whereas our target audience needs resources in French. Maybe we could put in a request to the site managers and get authorization to translate relevant resources. Let's keep an open mind about this so as to avoid redundancy and find complementary materials.

Maude, interrupting Luke, says: OK, where do we start?

Maude's prompt to get going was timely because both Luke and Daniel tended to be dreamers. Reminded to move forward, Luke then presented the instructional design process that had been adopted by the University and was available via the Intranet.

\section{Instructional design model}

Luke was inspired by various ADDIE-based models ${ }^{1}$ (Basque, 2004; Clark, 2011) as well as by NU's design process model ${ }^{2}$, but he mostly drew upon his own experience in adapting the NU model to the needs of new faculty, providing them, at a glance, with all of the design phases to be included in the tutorial (Figure 2).

\footnotetext{
${ }^{1}$ ADDIE is an acronym for : Analysis, Design, Development, Implementation, Evaluation

${ }^{2} \mathrm{NU}$ 's model was also ADDIE-inspired but was more synthetic, amalgamating some of the steps: 1) a preliminary phase (including analysis), 2) a development phase (including design) and 3) a delivery phase (including evaluation).
} 


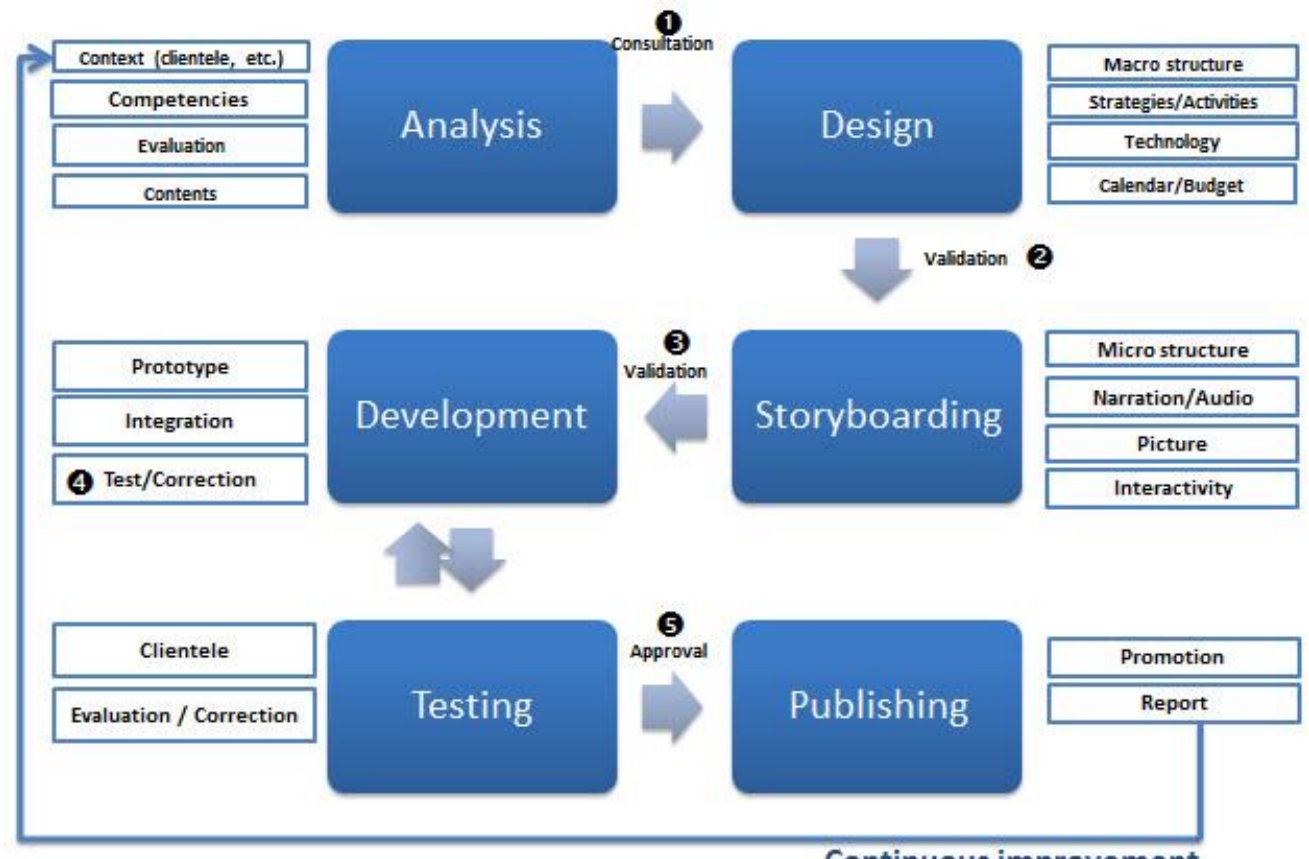

Continuous improvement

Note: The numbers shown in the model were added by the Steering Committee to represent actions recommended by the recently-appointed group of experts.

Figure 2: Design and development model of an online tutorial for the Vivacity project.

\section{Steering Committee meeting}

Cristina:Instead of having the same group of experts working together to develop all of the tutorials, couldn't we have one for each tutorial?

Karina: Can you imagine the number of experts that would require? Our people are already overloaded!

Cristina: I don't think we'd need that large of a group of experts. And I'd avoid any regular meetings of representatives from all five institutions. At that rate, we would never be able to deliver anything!

Roy: Basically, I think we need one representative from each college and one from NU to meet with members of the production team.

Josée: Why not add a student? After all, they are our target clientele!

Vincent: How are we going to find volunteer students? I'm not sure...

Josée: If we are not sure we can find any volunteers, we can pay a few of them.

Luke: How about we stick with the idea of one group of experts? I'm sure we already have everything we need for collaboration. And I believe that, with the number of instructors 
who are involved in this project, we should be able to get through the tutorials with each one pitching in just once a year. That shouldn't drain them too much!

Florence: As for students, what we're asking for may be a bit unrealistic. If we think the instructors may not be available, then it may also be the case for the students.

Luke: On the other hand, in the design process, there is a testing phase. It is expected that we would consult students at that stage.

\section{Meta-Reflection: Group of experts to initiate a collaborative culture}

Luke is concerned about the future of the project. Indeed, many funded initiatives like Vivacity disappear due to a lack of commitment from partners. He examines the literature to explore the intersection of issues related to culture and collaboration, namely Le Boterf (2008), and Schein (2004). He is inspired by these authors' efforts to find long-term collaborative levers. One of these levers is the creation of a group of experts. He hopes to mobilize faculty and instructors who are interested in information literacy. Furthermore, if there is one thing he has learned throughout his career, it is that the best advocates for change are those who were involved in making change happen.

\section{Preparatory work and choice of collaborative tools}

Over the next two months, Luke, Maude, and Daniel work to organize the experts' efforts: estimating the cost of the website, identifying targeted skills, proposing tutorials to be developed, choosing tools for collaboration and development, and finding information on tutorial development for the experts.

Luke had never participated in the development of a corporate website, his only experience being with blogs. So he entrusts this task to his new colleagues who are experts in information systems. 
Sebastian, the computer technician who was assigned to them, supports this aspect of the project throughout the design process.

Maude and Daniel were also working on information literacy well before their arrival on the project, basing their work on the standards of the Association of College and Research Librarians (2005). Thus, they had identified a first cut of future tutorials to be developed (Figure 3). Luke directed them to the revised version of Bloom's taxonomy which helped them determine the skills levels involved. After perusing the literature, they highlighted materials that related to information literacy. With the help of the web application Mindomo, they then documented everything as a conceptual map. Web references were archived in the Diigo application.

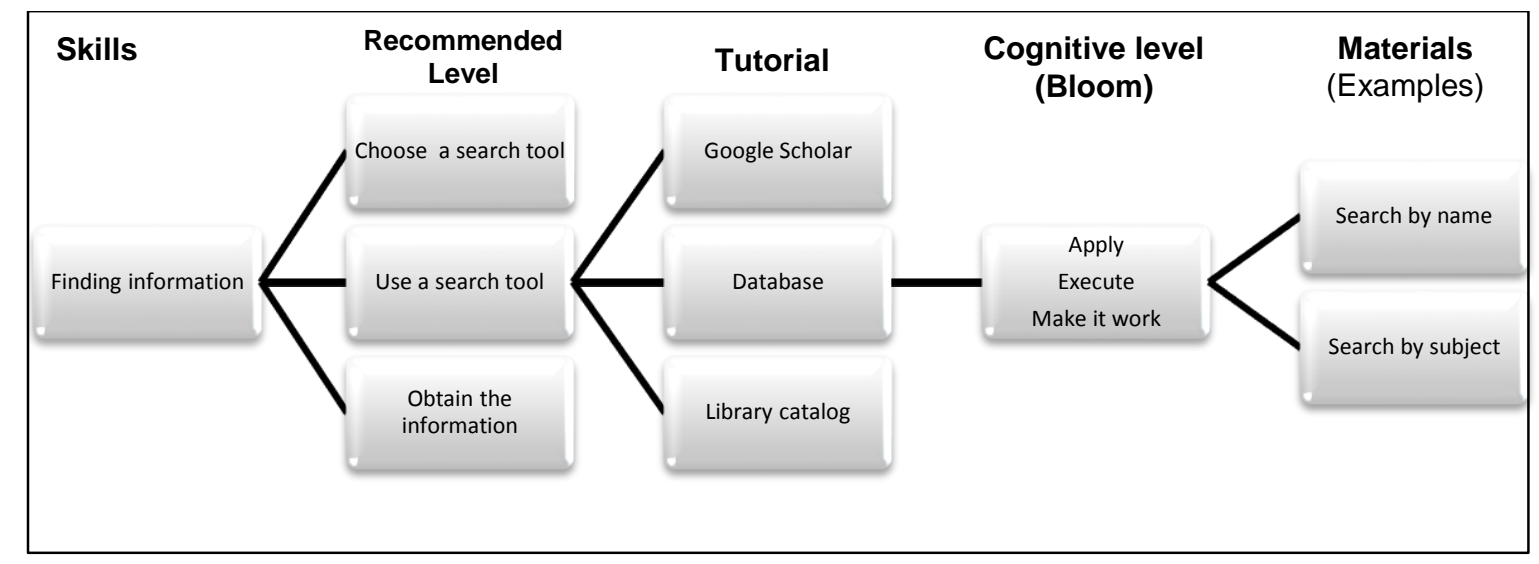

Figure 3 - Example: Dividing a skill into tutorials and materials to develop

Luke was concerned about the physical distance between Daniel and the rest of the team. He wanted Daniel to feel part of the same team even when he was physically not there. Over a twomonth period, they tried a variety of free collaboration tools appearing on Hart's list (2012), a reference in the field of instructional technologies. Finally, they opted for Skype, the most efficient and stable tool for audio conferencing. They also decided to download TeamViewer 
which not only enabled screen-sharing but also screen control. Since the group of experts would also have to collaborate at a distance, the team chose Google Docs.

Luke developed an instructional design template for use with Google Docs. It was very simple and easy to fill out. It included the following elements: context (clientele, needs, and features), targeted literacies and recommended levels, content items, evaluation criteria, estimated length of instruction, teaching strategy, general structure, and working schedule.

The two months of preparatory work was almost complete. The team were finalizing their development and production standards according to identified project priorities. For instance, tutorials had to be generic, easy-to-understand and to use, interactive, and easy to update. The visual aspects were also established.

\section{Meta-Reflection: Telecommuting}

Telecommuting was a big part of the Vivacity project. So Luke wanted to take the opportunity to help instructors develop new skills. He observed that, in fact, their information technology skill levels were highly variable. Given that the project involved fostering information literacy among students, it was obvious that the instructors themselves had to be comfortable using these same skills. And since they were located in different institutions and they were expected to continue cooperating after the grant, he intended to acquaint them with remote teamwork software. 


\section{Development of two experimental tutorials}

It was finally time for the first meeting of one group of experts and the team was excited. After the usual exchanges, Jean and Valerie were introduced to the Steering Committee. Luke explained the overall design process using his diagram (Figure 2) and described the roles and responsibilities of each member of the group. He realized that the instructors were relieved when he mentioned that, over the course of the next steps in the design process, they would only be expected to validate the ongoing progress of the tutorial development.

Thereafter, a discussion began about information literacy skills, each instructor giving concrete examples of situations in which students experience difficulties mastering skills needed to achieve the desired competency levels. Daniel was also involved since he had been teaching fulltime before being assigned to the Vivacity project. Maude came in to talk about her experiences with students. Luke realized how delighted the instructors were to share their professional experiences. This discussion helped crystalize the needs and expectations of the tutorials under development. Once the discussion turned to content, Luke began to intervene more often.

Maude: Prior to starting the project, we did an extensive review of the existing materials on the subject. In line with what we had discussed earlier, I think we really have to revamp our materials.

Valérie: Indeed, we should focus on three criteria of information evaluation, not on the six proposed by the Association of College \& Research Libraries (2005).

Jean: Perhaps we should do a pre-test to see if the students are indeed aware of these three criteria.

Daniel: You're right, that is what we should do. I think we can do that by using Captivate...

Luke: OK, before talking about the how-to, let's first be sure what we're trying to do. We must ensure that our materials align with our objectives. That has to be done before we can settle on the best strategy.

Daniel: Yup, that's right! Pants first, then shoes!

Luke: I agree with Valerie's idea on the three criteria. 


\section{Meta-Reflection: The guardian of the development process}

It was not unusual that Luke had to get experts back on track when he was helping them design their course. As often as not, they didn't even know what training outcomes were intended before they're unpacking their ideas on learning strategies. Even Maude and Daniel, despite their being full-time instructors on the project, jumped the gun at times. Luke felt like a killjoy when it happened because experts tend to get very excited over learning strategies. But he knows it's the right approach. He also knows that compliance with the chosen design process guarantees the quality of the tutorial to come. As an instructional designer, he must serve as the gatekeeper.

After having a full discussion on criteria, the experts eventually came to an agreement. Related to the learning strategy, Maude and Daniel provided some examples of tutorials on the Web with a similar theme. Valerie added an example of a tutorial from another college. Overall, this first brainstorming session oriented the project team (figure 4).

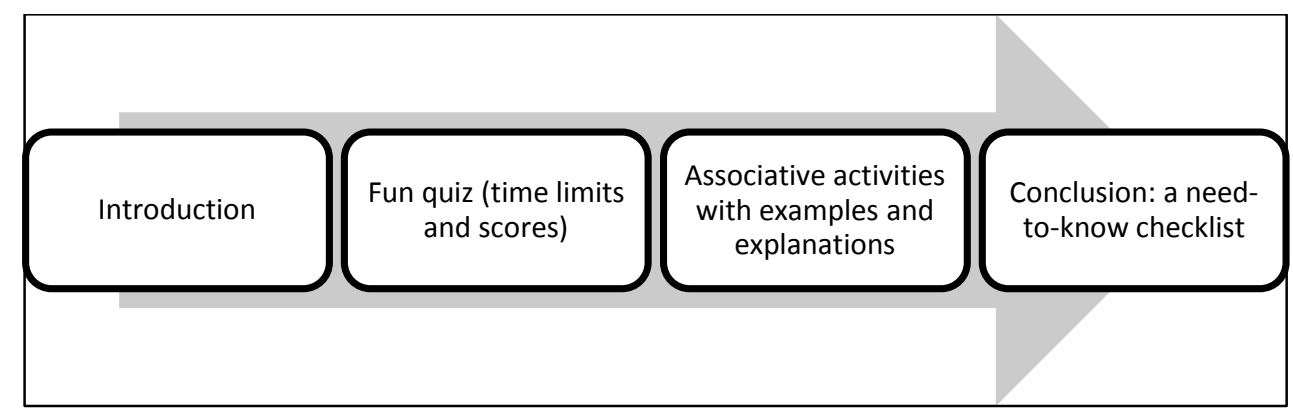

Figure 4 - Overall architecture of the first tutorial

Before ending the meeting, the team established a work schedule that would determine when instructors should provide feedback on each step of the design process. Maude also enrolled each of them in Google Docs and showed them how it works. As they had predicted, the meeting had 
the same mobilizing and enthusiasm-generating effect common to creative activities. Everyone thus left this first experts' meeting pleased with the collaborative experience, which set the tone for the 20 expert group meetings to follow. More than 40 faculty members and instructors participated in this type of brainstorming activity before the end of the project.

\section{Meta-Reflection: Online instructional design}

When Luke leads instructional design with experts, he always uses a whiteboard and markers. He follows Brien's steps to the letter (Brien was his former professor and mentor) and the process has always allowed him to develop cognitively relevant and interesting programs. The whiteboard usually allows him to draw a conceptual map of targeted knowledge-based skills. In general, experts are always delighted with the experience. With Vivacity, Luke worked with his first group of experts without a whiteboard, since there were no classrooms available at the time they were meeting. He noted that, even without a whiteboard, by having a template of the instructional design process available, he was able to promote linearity. In addition, Maude and Daniel already offered, in the specifications, examples of content related to the targeted skills, which significantly guided the discussion. After a few meetings, Luke realized he can no longer use Brien's model (1997), but not without some regret.

The following week, Maude and Daniel convened their second group of experts to address the topic of research tools. Maude and Daniel had been working on a prototype version. They did some online research and explored features of Captivate software. Luke was delighted with the dynamic presentation of his colleagues. Their ideas were relevant and their research commendable. 
Table 1 - Excerpt from the first part of the tutorial prototype

\section{CONTEXT}

\section{Types of tools used in information searches}

Target audience: Final year High School and undergraduate students

Audience characteristics:

Clientele acknowledge using Google. However, when asked about other research tools, they only mention Wikipedia. Colleges and university provide the same feedback.

Problems / Constraints encountered:

- Instructors had no use for long tutorials. They simply couldn't use all of their class time to go through a tutorial with their students.

- Generation Y students tend not to be motivated by tutorials.

- Since each institution has different search tools, each must be accounted for in the tutorial.

Use: In the classroom and computer labs

\section{Targeted skill}

- Information retrieval (students are able to find the information they need efficiently)

RECOMMENDED LEVELS

- Distinguish between different types of research tools and describe their main characteristics (library catalogs, databases, Internet search engines). (UNDERSTAND)

- Choose the right tool for the job. Use different types of research tools, generic databases and specific ones in accordance with his/her field of study). (APPLY)

It was decided to include two skill levels in the same tutorial to avoid redundancies that might have occurred had two separate tutorials been developed.

\section{CONTENT (Knowledge, Skills, and Attitudes) OBJECTIVES}

Comparisons between catalog-based data, databases, and Web-based data

- Raise awareness to the effect that Google does not have everything needed when conducting an online search $* * *$

- Identify what each tool allows you to find (books, articles, both and more) $* * *$

- Determine quality of information (source selection or not)

- Select organization of information (structured or not)

- Search (keywords vs crossed out fields and indexes);

- Determine purpose of use (appropriate for ...)

- Identify cost of access to all sources (if applicable).

Note: *** means important and erossed out means not necessary for this tutorial

\section{EVALUATION CRITERIA}

- can discriminate between different types of research tools: library catalogs, databases and search engines

- can choose the right research tool (library catalogs, databases and search engines) given a specific query 
Based on information generated by the various expert groups, Maude and Daniel tested a few screens using dummy content. It was at this point that Luke noted one of their limits.

Maude: MS Office images do not fit well with our Vivacity color scheme. And the drawings are from the 90s; they are just butt-ugly and outdated!

Daniel: The question is also whether we go with pictures or drawings?

Luke: Pictures are in. But they are quite expensive. And then again, fashions can change and pictures could become obsolete after a while. And if we want instructors to make modifications to them, we could have a problem with copyright.

Daniel: It's not much better with drawings, it seems.

Maude: Well, at least with drawings, you can change the colour of the t-shirt, change facial expressions without it costing us a fortune. You can also subscribe to an online bank of characters with faces and in various positions. On the other hand, there are some that we could do ourselves, if they are basic.

Luke: Doing our own would make it easier to have our own project colors. But maybe we could negotiate a special agreement with an illustrator to obtain a copyright.

After mulling it over, Luke hired an illustrator. In addition to producing characters, the illustrator drew a series of objects commonly found in tutorials: books, planets, locks, etc. The illustrator also paid a visit to the team to show them how to change colors of the t-shirts on the characters and how to use MS Office pictures to modify them in their own style.

Maude and Daniel each developed one of the prototype tutorials with Adobe Captivate. This was a conscious choice as they had long known that this software allows them to achieve a level of interactivity that other programs just can't. As they both began using this software, the prototype tutorials became a laboratory for them. Luke just loved sitting in on such a vibrant and creative activity but he had other duties to occupy his time. Furthermore, as coordinator of Vivacity, he had a lot of follow-up to do, such as reports and activities, and so on. Then, one morning, Daniel calls Luke out of the blue, his voice filled with frustration: 
Daniel: Luke, I'm working on my tutorial screens but I can't make them pretty. I don't have a lot of patience and above all I don't have Maude's talent. And I don't even think it's my job to be doing this!

Luke: What do you mean?

Daniel: Placing icons of the right size in the right place on the screen. Putting text here and there. Choosing colors... even counting pixels! Listen, I'm an instructor; I think a technician should be doing this...

Luke: You're right; I'll ask our directors to see if we can get a bona fide multimedia developer to go over your work when we get to the production phase.

Daniel: That would be much better. I just feel like I'm wasting my time.

After a lengthy harangue with his bosses, Luke managed to get the developer he needed (Sebastian) and his team began producing tutorials with a more professional look. The next step: testing the prototype tutorials with the target audience.

\section{Meta-Reflection: Professional or technician?}

Although his two colleagues are happy developing tutorials, Luke realizes that what they're doing could be done by technicians. Since joining Northern University, he had failed to convince the directors to hire a full-time developer. When seeking assistance, they automatically referred him to a computer technician who didn't have the right skill set, at all. As Luke became more familiar with some of the tools Maude and Daniel were using, he realized that a developer could have taken them further with regard to ergonomics and aesthetics. More importantly, the time saved during production could have been reinvested in other aspects of the project.

\section{Website development}

Along with the production of the tutorials, a lot of work had been done to achieve very detailed technical designs leading to the choice of three, free software packages for the Website. The 
work was presented to the Steering Committee by Maude who was proud to show what the site would look like when it went live. But the group's comments surprised the team:

Cristina: Why are you showing us the Website? That is not what we need; we need tutorials!

Luke: Yes, of course, but the tutorials have to go somewhere, don't they?

Rémy: We do not want project time and money invested on the container; what interests us is content.

Luce: (recently assigned to the project): I work at Northern University and we also want tutorials on our Website. But they must be as content-rich as the old site.

Florence: We can't do the same thing as the old site. It's way too outdated and just not appropriate for high school students.

Luke: The old site will be dismantled and the Vivacity project will take its place. That's the plan.

Christina: Will all of the content be used? Because the old site is still getting lots of hits...

Josée (Co-director) pipes up, as tempers flare: What we understand here is that you don't want us to put too much time into the development of the Website, although we do need one to host the tutorials. OK. We'll therefore focus on accessibility for instructors and faculty. I also remember that, at the beginning of the project, we agreed to work on a more attractive concept for students and also for instructors and faculty. So I propose we continue in this direction. Do you agree?

Everyone agreed, but a chill was in the air until the end of the meeting. Right afterwards, Luke chatted with the project directors. They attributed the hostile reaction to the fact that there were too many new faces on the Steering Committee and to the fact that the terms of partnership were not well known to all. The directors therefore decided to write a memo to all project partners to remind them of the project objectives.

Months passed but progress remained modest with regard to the Website. Luke had trouble monitoring Sebastian's work (his developer). Then, without warning, and six months into the Project, Sebastian quit his job. Only after leaving, did Sebastian tell him about his discomfort with the mandate which he felt was too complex for his skillset. He preferred to return to his former position. Luke contacted a team of computer technicians at the University but the team 
was already busy with the development of a Website for another department. As Luke had no control over them, even if he had told Florence about the alarming lack of progress with the Website, he knew that his project was not considered a priority for the institution. The strategy of announcing a launch date had barely made a difference as the beta site presented was woefully inadequate.

Month after month, the project team had continued to produce tutorials and, although several were ready for viewing, Luke could only provide faculty and instructors with temporary access, given the state of the Website. Nonetheless, they called him regularly to access this new teaching material, including those who, only a few months earlier, had asked his team to not invest time and energy in the Website. To complicate matters further, Luke had problems with the Website graphic artist, noticing from what she was producing, that she didn't seem to have the skills required to do the job.

\section{Meta-Reflection: limits of the project coordinator role}

Luke does not like this turn of events. As the project advances, the more concerned he is about the Website, even if he doesn't show his frustration in public. He tries a variety of strategies such as delivery dates with milestones, unannounced visits at the IT office, and systematic requests to his superiors, but none are successful. He thus discovers all of the limitations of being a project coordinator. He knows he had always done well in that role before and he has always managed to deliver on time. But that was when he was working in the private sector. In the public sector, or at least in this institution, priority management appears to be random. The failure to meet deliverables as set by the Steering Committee and ultimately by the funder, leaves him feeling 
incompetent. He now realizes that should he ever be asked to coordinate another project like this one, he'll know to impose clear and precise conditions for success.

\section{Testing tutorials}

The next step was to test the project tutorials. To do so, Luke designed a two-part questionnaire, which was subsequently and repeatedly validated with students. The first part (Table 2) assessed the students' perceptions of their own learning.

Table 2 - Evaluation model retained after testing (section 1)

\begin{tabular}{|c|c|c|c|c|c|c|c|c|}
\hline \multirow[t]{2}{*}{ Statement } & \multicolumn{4}{|c|}{ Before } & \multicolumn{4}{|c|}{ After } \\
\hline & $\begin{array}{l}\text { Not at } \\
\text { all } \\
\text { mastere } \\
\text { d }\end{array}$ & $\begin{array}{l}\text { Somew } \\
\text { hat } \\
\text { mastere } \\
\text { d }\end{array}$ & $\begin{array}{c}\text { Mastere } \\
\mathrm{d}\end{array}$ & $\begin{array}{l}\text { Comple } \\
\text { tely } \\
\text { mastere } \\
\text { d }\end{array}$ & $\begin{array}{l}\text { Not at } \\
\text { all } \\
\text { mastere } \\
\text { d }\end{array}$ & $\begin{array}{c}\text { Somew } \\
\text { hat } \\
\text { mastere } \\
\text { d }\end{array}$ & $\begin{array}{c}\text { Maste } \\
\text { red }\end{array}$ & $\begin{array}{c}\text { Comple } \\
\text { tely } \\
\text { mastere } \\
\text { d }\end{array}$ \\
\hline $\begin{array}{c}\text { In my own } \\
\text { words, I } \\
\text { can } \\
\text { explain } \\
\text { what a } \\
\text { primary } \\
\text { and } \\
\text { secondary } \\
\text { source is }\end{array}$ & 0 & 0 & 0 & 0 & 0 & 0 & 0 & $\mathrm{O}$ \\
\hline $\begin{array}{l}\text { I use tools } \\
\text { other than } \\
\text { Google to } \\
\text { find } \\
\text { relevant } \\
\text { informatio } \\
n\end{array}$ & 0 & 0 & 0 & 0 & 0 & 0 & 0 & $\mathrm{O}$ \\
\hline
\end{tabular}

Once the first part was completed, the student would continue onto the second part regarding the quality of the tutorial. Luke chose eight quality criteria inspired by the IBIS analysis grid (Thot 
Cursus, 2009), all of which can be commented on individually by students: (1) duration, (2) speed, (3) pictures/graphics/illustrations, (4) ease of navigation, (5) interactivity (relevance and frequency), (6) information provided (quantity, clarity, relevance), (7) learning achieved, (8) interest in viewing more tutorials.

Luke then established a policy regarding testing tutorials. With the aim of promoting participation, the directors approved the plan to have three monthly drawings of an iPod Touch. Luke advertised the competition in student computer labs. He hoped to have at least a dozen students test each tutorial. This was the criterion set by the team for each academic level (community college or university). At the college level, he asked some of the project partners to find testers at their institutions. He needed a procedure that could be repeated, since 30 tutorials would have to be tested.

After two weeks, the results were still inconclusive, both at the college level and at Northern University. Luke was disappointed. It was impossible to correct the tutorials with so little feedback. He discussed the situation with his colleagues:

Daniel: As for my colleagues, I can pick up the phone and call them directly instead of just sending them an email.

Luke: As for the University, there is still that Website that I have not yet been able to use... but the webmaster told me about a Project Facebook account he's set up...

Daniel: Don't give up, Luke, because we need that data; it will allow us to promote our site and our tutorials to institutions beyond our immediate partners.

Luke: You're right! If we don't get it, it could jeopardize any future requests for cooperation, even grant applications.

Maude: We'll likely even have to delay our launch if getting test results continues to be a problem, since it will take some time to modify the tutorials ...

Daniel: Well, we'll just have to live with that. We must be sure our tutorials work before we can deliver them. 
By using the Website and the Project Facebook account, Luke started getting better results. But there was little input from the colleges. They used their Websites to promote the tutorials, but it made no difference in the data received. There was only one alternative left, plan C; get faculty and instructors involved. At a Steering Committee meeting, Josée asked her experts, in private, to set aside some time to test the tutorials during their own courses. She reminded them that they had signed a partnership agreement. This finally bore fruit as, during the next quarter, meaningful data began to trickle in.

After this first round of testing, Luke already noted a few trends. The average satisfaction rate was $80 \%$ and there was an improvement rate of $20-35 \%$ in targeted skills. The Steering Committee was satisfied. Student feedback allowed the team to make necessary corrections. The main criticism concerned the anticipated reading speed or the length of the tutorials; sometimes students found an exercise too strenuous or a quiz too many.

\section{Meta-Reflection: Management support in testing}

Luke feels reassured. He finally has information on the tutorials after wandering in a sea of fog for months on end. He had been unable to continue developing new tutorials without any student feedback. Even if there had been a long delay in reaching this point because of the requisite testing, Luke is happy that it has been taken seriously by the Vivacity directors. He knows that this step is often overlooked because of a lack of time, staff or money. It is therefore not faculty and instructors who have to be convinced of the usefulness of testing, it's the directors. 


\section{Tutorial development}

Having produced more than 20 tutorials in assembly-line fashion, the team's performance met with Luke's satisfaction. Although the Website had been delayed, there had been no delays with tutorial production.

Several tutorials did have common characteristics. However, team members tried to innovate as much as possible when working on a new tutorial. Luke saw to that. So they elaborated various learning strategies while remaining focused on the objectives and content of the tutorials: they used metaphors, analogies, queries, simulations, puzzles, associations, competitive games, funny quizzes, comparisons, demonstrations, and interactive simulations (especially for instructional software).

Several strategies required software like Captivate, but others were developed using a variety of software solutions. For instance, the following discussion between members of one group of experts working on "How to write a search question" tutorial, suggests the need to think beyond a single software solution:

Daniel: The student should be able to write in each window of the tutorial... Maude: But with Captivate, you cannot keep a record of what he's writing ...

Simon: Can't that be simulated? Like, when the student selects a question he is guided through the process?

Luke: Let's not get married to Captivate, ok? If we need other software to develop this tutorial, we'll see about that later. For the time being, what do we need to achieve the goal?

Maude: I think that, ideally, students should be able to write in the tutorial and we should be able to keep track of what they are writing; let them find their own research questions rather than using our suggestions which have no meaning for them.

Claire: They should be accompanied, guided by the tutorial. 
Once the instructional design was completed by the group of experts, but before Maude and Daniel finished the work, Luke met with the directors who gave him a budget to develop the specific tutorial with a team from Northern University that specialized in multimedia development. Luke would obtain the same kind of contract four other times for tutorials that could not be developed only with Captivate. These developments used PHP, Flash, Java, and even HTML5 software. Also, some Web applications were available under Creative Commons licenses and were obtained from other universities, Australian and American, and were slightly modified to suit the project.

Even though the team was highly responsive to student feedback, they also relied on feedback from faculty and instructors. For instance, many of the faculty and instructors wanted a summary of the content of each tutorial. Checklists were thus created and made accessible both within the tutorial and on the Website. Another comment from Northern University focused on illustrations that looked "childish." As this comment didn't come from any of the students when tested, the team decided to keep the illustrations. Luke simply reminded faculty and instructors that, since the tutorials were done using a Creative Commons license, they had all the latitude they needed to delete, modify or replace them. Three of the team members were even trained in Web editing to ensure language consistency, which related to another comment from faculty and instructors. 


\section{Conclusion}

A few days after the unofficial start of Vivacity, Luke accepted another position within Northern

University. In a team meeting, which included two directors, he was reassured about the future of the project.

Josée: It's sad you're leaving. You were able to move this project forward with tact and under difficult conditions.

Luke, smiling: You're right! It was not always easy. And I have to admit that what bugged me most in this project was the testing and the never-ending Website development. I would have liked that to go better.

Daniel: Nevertheless, we're on time. We even have a few more months to go!

Florence: And the new grant we obtained, thanks to you, is a legacy for us. It'll allow us to improve on our work.

Luke: One thing I regret is not hearing much about faculty and instructor use of our tutorial.

Maude: Well, as a matter of fact, I just got some feedback yesterday from two faculty members. Do you remember Sonia? She used the "How to put together a bibliography" tutorial in one of her classes. She said the students really got on board with our little game! There's also Caroline who developed a one-day course in which she uses four of our tutorials. The funny thing is that it was highly successful even though she teaches a graduate-level course using undergraduate-level content! So I think our tutorials are responding to a real need.

Florence: Another instructor somehow heard about Vivacity and contacted me. I sent him the temporary links to the tutorials and he has added them to his course website.

Daniel: There are lots of cases like these. I think we're just at the beginning ... and all this without even having an official Website!

Luke: This has been a great experience collaborating with all of you. I promise you that I will keep promoting the Vivacity project in my new job!

A few weeks later, as Luke was preparing his files for his replacement, he thought about his last two years in this department. He knew he should never forget that he was, first and foremost, an instructional designer, even though he was coordinating a major project. This happened to him several times during the Vivacity project, much to his regret. He also knew that managerial support was crucial during certain phases of a project since, as coordinator, he did not always 
have the decision-making power he required. Finally, it was clear to him that the Vivacity project required skills he simply did not possess. Indeed, he had to assume several new roles: that of the confident director, the public relations guy, and even the clever politician.

When he looked at the future of the project, he no longer regretted not being in charge anymore. The next phase of the project would, more than ever, require the skills of a director, a publicist, and a politician and less and less those of an instructional designer. And at this point in his career, he was sure that he never wanted to leave his chosen profession as a designer! 


\section{References}

Association of College and Research Libraries (ACRL). (2008). Standards or Distance Learning Library Services. Retrieved on August 26, 2011, from http://www.ala.org/ala/mgrps/divs/acrl/standards/guidelinesdistancelearning.cfm

Basque, J. (2004). How are ICTs changing the instructional design practices of the university professor? International Journal of Technologies in Higher Education, 1(3), 7-13. http://www.ritpu.org/IMG/pdf/basque.pdf

Brien, R. (1998). Science cognitive - Formation (3 ed.). Québec: Presses de l'Université du Québec.

Clark, D. (2011). ADDIE. Retrieved May 1st, 2013, from http://www.nwlink.com/ donclark/history_isd/addie.html

Hart, J. (2012). Centre for Learning and Performance Technologies. Retrieved January 20th 2013, 2013, from http://c4lpt.co.uk/

Le Boterf, G. (2008). Travailler efficacement en réseau; une compétence collective. Paris: Éditions d'organisation.

Schein, E. (2004). Organizational Culture and Leadership (3 ed.). San Francisco: Jossey-Bass.

The New Media Consortium, \& Educause Learning Initiative. (2011). The 2011 Horizon Report. 33. http://net.educause.edu/ir/library/pdf/HR2011.pdf

Thot Cursus. (2009). Grille d'analyse Ibis. Outil de travail. Thot Cursus. Retrieved from http://tinyurl.com/cktl25

\section{Websites:}

Revised Version of Bloom's Taxonomy (A. Churches): http://edorigami.wikispaces.com/Bloom\%27s+Digital+Taxonomy 